\section{Commentary: Coronavirus, cysts, and catheters}

\author{
Olugbenga Okusanya, $\mathrm{MD},{ }^{\mathrm{a}}$ and \\ Ibrahim Sultan, MD ${ }^{\mathrm{b}, \mathrm{c}}$
}

The emergency of the novel virus severe acute respiratory syndrome coronavirus 2 (coronavirus disease 2019 [COVID-19]) has changed the global health landscape. First detected in China at the end of 2019, the virus rapidly spread to every developed and undeveloped country in the world. ${ }^{1}$ Currently, more than 24 million people have been infected, with more than 800,000 deaths. ${ }^{2}$ The disease primary manifests as a respiratory illness, but a myriad of other organ systems, including the cardiovascular, neurologic, and musculoskeletal systems, are known to be involved. ${ }^{3}$ Respiratory disease can range from asymptomatic and mild to severe requiring mechanical support, extracorporeal membrane oxygenation, or even lung transplantation. ${ }^{4}$ Currently, the most common finding on imaging is diffuse bilateral ground-glass opacities.

Brahmbhatt and colleagues ${ }^{5}$ in their case report describe a patient with severe acute respiratory syndrome coronavirus 2 infection who developed bilateral cystic lung changes. These changes were not found in the patient before infection and appear to have resolved with time and percutaneous computed tomography-guided drainage. The patient, who had significant comorbidities, presented and was managed with escalating noninvasive oxygenation strategies but developed a left pneumatocele and right-sided cyst. Drainage showed an exudative fluid analysis without bacterial growth. The patient recovered and was discharged.

There a few scattered reports of COVID-19-related cystic change, with some showing superinfection. ${ }^{6}$

From the ${ }^{\mathrm{a} D e p a r t m e n t}$ of Surgery, Thomas Jefferson University Hospital, Philadelphia; ${ }^{\mathrm{b}}$ Department of Cardiothoracic Surgery, University of Pittsburgh School of Medicine, Pittsburgh; and ${ }^{\mathrm{c}} \mathrm{Heart}$ and Vascular Institute, University of Pittsburgh Medical Center, Pittsburgh, Pa.

Disclosures: The authors' institution receives research support from Medtronic and AtriCure. These are not related to this work. The authors reported no conflicts of interest.

The Journal policy requires editors and reviewers to disclose conflicts of interest and to decline handling or reviewing manuscripts for which they may have a conflict of interest. The editors and reviewers of this article have no conflicts of interest.

Received for publication Sept 3, 2020; revisions received Sept 3, 2020; accepted for publication Sept 24, 2020; available ahead of print Sept 28, 2020.

Address for reprints: Ibrahim Sultan, MD, Division of Cardiac Surgery, 5200 Centre Ave, Suite 715, Pittsburgh, PA 15232 (E-mail: sultani@upmc.edu).

JTCVS Techniques 2020;4:356-7

2666-2507

Copyright $@ 2020$ The Authors. Published by Elsevier Inc. on behalf of The American Association for Thoracic Surgery. This is an open access article under the CC BY-NCND license (http://creativecommons.org/licenses/by-nc-nd/4.0/).

https://doi.org/10.1016/j.xjtc.2020.09.034

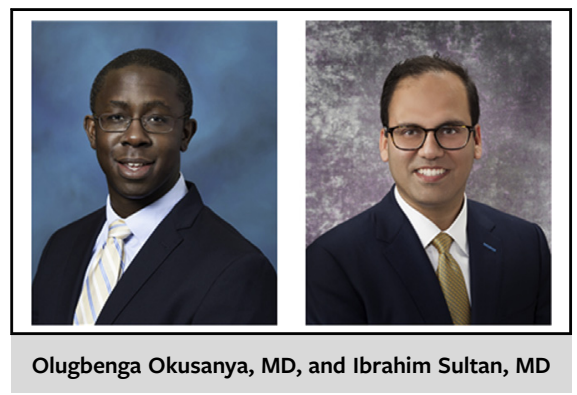

CENTRAL MESSAGE

Lung parenchymal changes associated with COVID-19 may include cystic changes.

However, with the absence of a secondary infection or barotrauma, it is believed that the acute respiratory distress syndrome related to the lung infection is sufficient to cause these lung changes. Drainage of these collections is somewhat controversial. Cystic lung changes or pneumatoceles during the course of other pulmonary infections are usually managed without intervention and resolve with time. ${ }^{7}$ However, these lesions if infected or symptomatic require drainage or surgical therapy. In patients who are critically ill with COVID-19, superinfection is believed to be common; thus, given this, some may advocate early drainage of discrete lesions amenable to safe percutaneous access.

As COVID-19 continues to spread and potentially reinfect patients, we must all broaden our knowledge base and clinical expertise in treating these patients. It is critical that any significant sequelae of this disease are recognized and best efforts are made to develop expert management strategies.

\section{References}

1. Guan WJ, Ni ZY, Hu Y, Liang W, Ou C, He J, et al. Clinical characteristics of coronavirus disease 2019 in China. N Engl J Med. 2020;382:1708-20.

2. Johns Hopkins University. COVID-19 Dashboard. Available at: https://corona virus.jhu.edu/map.html. Accessed August 26, 2020.

3. Stawicki SP, Jeanmonod R, Miller AC, Paladino L, Gaieski DF, Yaffee AQ, et al. The 2019-2020 novel coronavirus (severe acute respiratory syndrome coronavirus 2) pandemic: a Joint American College of Academic International Medicine-World Academic Council of Emergency Medicine Multidisciplinary COVID-19 working group consensus paper. J Glob Infect Dis. 2020; 12:47-93.

4. Sultan I, Habertheuer A, Usman AA, Kilic A, Gnall E, Friscia ME, et al. The role of extracorporeal life support for patients with COVID-19: preliminary results from a statewide experience. J Card Surg. 2020;35:1410-3.

5. Brahmbhatt N, Tamimi O, Ellison H, Katta S, Youssef J, Cortes C, et al. Pneumatocele and cysts in a patient with severe acute respiratory syndrome coronavirus 2 infection. J Thorac Cardiovasc Surg Tech. 2020;4:353-5. 
6. Castiglioni M, Pelosi G, Meroni A, Tagliabue M, Uslenghi E, Salaris D, et al. Surgical resections of superinfected pneumatoceles in a COVID-19 patient. Ann Thorac Surg. June 27, 2020 [Epub ahead of print].
7. Kaira K, Ishizuka T, Yanagitani N, Sunaga N, Hisada T, Mori M. Pulmonary traumatic pneumatocele and hematoma. Jpn J Radiol. 2009; $27: 100-2$. 